\title{
The Role of Non-Governmental ORgANIZATIONS IN INTERNATIONAL HUMAN Rights Standard-SetTing: A Prerequisite of DEMOCRACY
}

\author{
Theo van Boven*
}

\section{INTRODUCTION}

It is now common knowledge that many Non-Governmental Organizations (NGOs) play an important role in the collection and dissemination of facts concerning alleged violations of human rights. Many institutions and organizations, such as the United Nations, rely heavily on information concerning violations of human rights provided by NGOs and groups. It is less well known that a good number of NGOs are performing many other functions for the sake of human rights and fundamental freedoms. The fact that NGOs also make contributions-and often very significant ones-to the development of human rights norms is an aspect of NGO activities which is generally overlooked. Most articles and commentaries written on the role of NGOs in the promotion and protection of human rights tend to ignore standard-setting activities. This article is written on the assumption that non-governmental participation in international standard-setting activities will develop further as a continuing and growing trend in international law and international relations. Additionally, this article argues that such participation is a necessary requirement of democracy.

International relations, and in particular the treaty-making process, is traditionally the privileged domain of governments as representatives of Nation States. Governments are the main actors. The term "Non-Governmental Organizations" implies that they are only marginal or auxiliary bodies. Marc Nerfin, the president of the International Foundation for Development Alternatives, thought that the concept of NGOs was "politically unacceptable because it implies that government is the centre of society and people its pe-

* Professor of Law, University of Limburg, Maastricht (Netherlands); Former Director of the Division of Human Rights of the United Nations. 
riphery." Similar criticism was voiced by Johan Galtung when he said "there are the international 'non-governmental' organizations, so called by governments-a term we should not necessarily accept. International peoples' organizations may be more accurate, not by that necessarily implying that governments are non-people organizations." 2 This discussion of terminology is not just a play of words. It raises issues of the representative character and the legitimacy of international actors and of the democratic quality of international relations, including treaty-making and other standard-setting processes.

The United Nations Charter, in providing for consultative arrangements with NGOs, exclusively reserved this facility to matters falling within the competence of the Economic and Social Council. ${ }^{3}$ Human rights fall within this category, but non-governmental involvement in such hard-nosed political matters as peace and security or disarmament was not accepted in the original philosophy of the UN Charter. Political issues were apparently considered the monopoly of inter-governmental cooperation, while economic, social and human rights issues warranted some degree of non-governmental involvement by means of consultative relationships. This dichotomy, between political matters on the one hand and economic, social and human rights matters on the other, is no longer valid. In his latest annual report on the work of the Organization, the Secretary General of the United Nations explicitly recognized the constructive role of NGOs in the broad area of peace. After having paid tribute to the efforts of NGOs when he reviewed UN activities in the field of human rights, ${ }^{4}$ the Secretary-General quite correctly highlighted the activities of NGOs in support of peace. He stated: "for the size and strength of the constituency of peace, a great deal of credit is due to non-governmental organizations around the world. Their tireless work in many vital areas has complemented and supported the efforts of the United Nations."' Along similar lines, the Soviet legal scholar Rein Mullerson, expert member of

1. Nerfin, The Future of the United Nations System; Some Questions on the Occasion of an Anniversary, in Dev. Dialogue 1, 25 (1985).

2. Johan Galtung, The United Nations Today: Problems and Some Proposals. Lecture Delivered on the Occasion of His Appointment as Visiting Professor on the Röling Chair in International Peace and Conflict Research, Faculty of Law, University of Groningen (Oct. $24,1988)$.

3. U.N. CHARTER art. 71.

4. Report of the Secretary General on the Work of the Organization, U.N. Doc. A/ $44 / 1, \S$ VII (Sept. 1989).

5. Id. at $\S \mathrm{XV}$. 
the Human Rights Committee, recently expressed his appreciation for the active involvement of NGOs in the broad political arena. He wrote: "I want to stress the growing importance of non-governmental organizations in the law-making process of the international arena, that is, the role of world public opinion. These organizations often express values and interests common to mankind as a whole. Although states remain the main law-making authorities, they have to take into account the will of various democratic, antiwar and antinuclear movements." 6

It may appear that NGOs can be equated with peoples' organizations or popular organizations. While some NGOs could qualify as such, the majority of NGOs serve more limited purposes. The variety among NGOs is nearly endless. For present purposes this discussion will be limited to those NGOs which play a role in international human rights standard-setting. In this respect it is useful to look into the relevant resolution of the UN Economic and Social Council. This resolution spells out the arrangements for consultation with non-governmental organizations, including principles to be applied in the establishment of consultative arrangements. ${ }^{7}$ Two functions are explicitly mentioned which NGOs are expected to carry out. First, NGOs are expected to give expert information or advice on matters in which they have special competence. Second, they are expected to express views in representing important elements of public opinion in a large number of countries. ${ }^{8}$ In other words, the contributions of NGOs rest on two premises: their expertise and their representative character.

\section{Some Historical Notions}

The involvement of NGOs in the process of human rights standard-setting is, generally speaking, a recent phenomenon. Nevertheless, there are examples of NGOs which have been active for a long time in international campaigns against slavery and against the traffic in women and children. NGOs created a climate favorable to the conclusion of international conventions in these areas. The Anti-Slavery Society, which celebrated its 150 th anniversary last year, should be mentioned with honor. Another prestigious NGO, the International Committee of the Red Cross, has been in-

6. Mullerson, New Thinking by Soviet Scholars; Sources of International Law: New Tendencies in Soviet Thinking, 83 AM. J. OF INT'L L. 494, 512 (July 1989).

7. Resolution 1296 (XLIV) of the Economic and Social Council (May 23, 1968).

8. Id. 
strumental in developing standards of international humanitarian law. Examples are the 1864 Geneva Convention for the Protection of War Victims, to the 1977 Protocols in addition to the Geneva Conventions of $1949 .^{\circ}$ The International Association for Labour Legislation initiated the conclusion of international labor conventions in Berne in 1905, 1906 and 1913, which were the forerunners of the many conventions adopted in later years by the International Labour Organization. ${ }^{10}$

Of historic importance was the role played by the representatives of NGOs who were invited to serve as consultants to the United States delegation at 1945 San Francisco Conference, which accomplished the drafting of the United Nations Charter. At a crucial stage of the conference it became apparent that the draft charter was very weak on human rights, and consequently a delegation of non-governmental representatives carried out an urgent démarche with U.S. Secretary of State Stettinius. The NGO representatives emphasized the need for expeditious and effective action by the United States to strengthen the UN Charter with respect to its future role in the area of human rights. It was stated by the delegation that the proposals submitted by them were not the program of one or two organizations in the United States, but reflected fundamental desires of the vast majority of people. ${ }^{11}$ The démarche had the desired effect. The United States succeeded in persuading the other major powers, and, as a result, the emphasis on human rights in the UN Charter became much stronger than the reference to human rights in the earlier Dumbarton Oaks proposals. The nongovernmental input was officially acknowledged in a passage of Secretary of State Stettinius' report to President Truman. The relevant part of the report reads:

In no part of the deliberations of the Conference was greater interest displayed than by the group of American consultants representing forty-two leading American organizations and groups concerned with the enjoyment of human rights and basic freedoms to all peoples. They warmly endorsed the additions to the statement of objectives. Beyond this they urged that the Charter itself

9. Youssoufi, Le rôle des organisations non gouvernementales dans la lutte contre les violations des droits de l'homme, l'apartheid et le racisme, in VIOLATIONS DES DROITS DE L'HOMME: QUEL RECOURS, QUELLE RESISTANCE? UNESCO, 109, 114 (1983).

10. E. SChwelb, Human Rights and the International Community 18 (1964)

11. O. Nolde, Free and Equal human Rights in Ecumenical Perspective; With reflections on the Origin of the Universal Declaration of Human Rights, with an introduction by Charles Habib Malik 21-24 (1968) [hereinafter INTroduction MALIK]. 
should provide for adequate machinery to further these objectives. A direct outgrowth of discussions between the United States delegation and the Consultants was the proposal of the United States delegation in which it was joined by other sponsoring powers that the Charter [Article 68] be amended to provide for a Commission on Human Rights of which more will be said later. ${ }^{12}$

A major operation in UN human rights standard-setting was the adoption of the Universal Declaration of Human Rights in 1948, and the 1966 International Covenants on Human Rights, including the Optional Protocol to the International Covenant on Civil and Political Rights. Together these instruments constitute the International Bill of Human Rights, the drafting of which was considered a priority task for the United Nations at the San Francisco Conference. Some NGOs played a considerable role in the drafting of certain articles of the Universal Declaration of Human Rights, and of the corresponding provisions in the International Covenants. As Charles Malik ${ }^{13}$ recalled in 1968, article 16 of the Universal Declaration on the Rights of the Family owes much of its inspiration to Catholic sources. In addition, the wording of article 18 on Freedom of Religion or Belief can largely be attributed to Dr. Nolde, the former Director of the Commission of the Churches on International Affairs of the World Council of Churches. ${ }^{14}$ A study on the "travaux préparatoires" of the International Bill of Human Rights reveals that NGOs did participate in the debates on the drafting of texts, at least on the level of the Commission on Human Rights and its drafting group, but they were not entitled to formally move proposals in their own name. In order to get their proposals examined on the floor, the NGOs needed the sponsorship of governmental representatives. In this respect Charles Malik noted: "the non-governmental organizations, therefore, served as batteries of unofficial advisers to the various delegations, supplying them with streams of ideas and suggestions." And he described the shaping of the Universal Declaration in the following terms: "the genesis of each article, and each part of each article, was a dynamic process in which many minds, interests, backgrounds, legal systems and ideological persuasions played their respective determining roles."15

12. Id. at 25 .

13. In the early years Mr. Malik was the Lebanese member of the Commission on Human Rights and Chairman of the Third Committee of the UN General Assembly which adopted the Universal Declaration.

14. INTRODUCTION MALIK, supra note 11 , at 11 .

15. Id. at 11-12. 
The "travaux préparatoires" of the International Bill of Human Rights indicates that predominantly Western-oriented NGOs took an active interest in this process of international legislation. ${ }^{16}$ Among these NGOs, representatives of Jewish and Christian organizations took a keen interest in matters of immediate concern to them. They acted in close cooperation with governmental representatives, who were sympathetic to these NGO concerns. But at the end of the day the governmental representatives were the decisive actors; they had the power of decision-making. More recent developments regarding the role of NGOs in international human rights standard-setting indicate that important changes are progressively taking place in the spectrum and outlook of NGOs, in their methods of work and in their relationships with governments. But one fundamental aspect has not changed; in the final analysis, governments are the decision-makers with regard to the contents and the adoption of conventions and other international human rights instruments.

\section{Some Areas of Special NGO Interest}

Nongovernmental input in human rights standard-setting of a whole range of organizations has had a substantial effect. Notable examples of such organizations are the International Labour Organization, the Council of Europe, and the Organization of American States. However, of the greatest importance is the impact of NGO activities on standard-setting carried out in the framework of the United Nations, which is the most comprehensive and central agency for the development and codification of international human rights norms. As pointed out in connection with the drafting of the International Bill of Human Rights, Jewish and Christian NGOs traditionally took an active interest in establishing international norms on freedom of religion or belief. They have continued to push for the elaboration of more detailed standards in this area, which finally resulted in the adoption in 1981 of the Declaration on the Elimination of All Forms of Intolerance and Discrimination Based on Religion or Belief. Whether the Declaration should be followed by a convention on the subject is a matter of protracted discussion. ${ }^{17}$ Also, the related issue of conscientious objection to

16. M. Bossuyt, Guide to the "Travaux Preparatoires" of the International Covenant on Civil and Political Rights 823 (1987).

17. See on this issue the Working Paper prepared by Theo van Boven and submitted to the forty-first session of the Sub-Commission on Prevention of Discrimination and Protection 
military service has long been an interest of peace movements, such as the International Peace Bureau, War Resisters International and the Friends World Committee for Consultation. It is partly due to their unrelenting efforts over a period of some fifteen years through publications, written and oral submissions and a good lobbying strategy with interested government representatives, that the UN Commission on Human Rights recognized that the right to conscientious objection to military service is a legitimate exercise of the right to freedom of thought, conscience and religion. ${ }^{18}$

The following discussion will highlight three other areas of special interest to NGOs, where these organizations played and are still playing an instrumental role in human rights standard-setting activities. The first area is the abolition of torture and related issues, including the rights of detainees and prisoners. The second area is the rights of the child. The third area concerns the rights of indigenous peoples.

The impact of NGO efforts on UN standard-setting to protect persons subjected to detention or imprisonment is a matter of public record, and a good deal of literature is available on this subject. ${ }^{19}$ It was not by coincidence that the process leading to a series of international instruments on the protection of persons subjected to detention or imprisonment started in the UN General Assembly in 1973. In this respect, two events were of major significance. The first of these events was the one-year campaign for the Abolition of Torture launched by Amnesty International in December 1972, with the support of a broad range of NGOs. This campaign included the publication of a "Report on Torture" and the holding of a major international conference. The campaign had an important impact on the media, public opinion, and the sensitivity of governments. The other significant event was the military coup d'état in

of Minorities under the item: Elimination of All Forms of Intolerance and Discrimination based on Religion or Belief, U.N. Doc. E/CN.4/Sub.2/1989/32.

18. Commission on Human Rights Resolutions 1987/46, of March 10, 1987 and 1989/59 of March 8, 1989.

19. See generally N. Rodley, The Treatment of Prisoners under International Law 17-43 (1987); J. Burgers \& H. Danelius, The United Nations Convention Against Torture; A Handbook on the Convention against Torture and Other Cruel, Inhuman or Degrading Treatment or Punishment (1988); see also V. Leary, $A$ New Role for Non-Governmental Organizations in Human Rights: a Case Study of NonGovernmental Participation in the Development of International Norms on Torture, in U.N. Law Fundamental Rights: Two Topics in International Law 197-210 (A. Cassese ed. 1979); Weissbrodt, The Contribution of International Non-Governmental Organizations to the Protection of Human Rights, in Hum. RTS. IN INT'L L., Leg. \& Pol'y Issues 403, $429-$ 30 (T. Meron ed. 1984) 
Chile on September 11, 1973, with its concomitant acts of brutality and cruelty against the life and the integrity of the human person, which profoundly shocked international public opinion. These events, together with other factors such as victories for democracy in Greece and Portugal, mobilized forces in governmental and nongovernmental circles and created a climate conducive to developing a comprehensive program for the protection of the human person against torture and other cruel, inhuman or degrading types of punishment. An important part of that program aimed at strengthening the normative basis by way of standard-setting activities. Thus, the General Assembly, inspired by non-governmental ideas, set out the following normative lines: (a) rules against torture and ill treatment, (b) safeguards against arbitrary arrest and detention, (c) professional ethics for police and other law enforcement officers, and (d) professional ethics for medical personnel. ${ }^{20}$

Now, some fifteen years later, we note that the following UN international instruments resulted from this program:

(1) The Declaration on the Protection of All Persons from Being Subjected to Torture and Other Cruel, Inhuman or Degrading Treatment or Punishment (1975);

(2) Code of Conduct of Law Enforcement Officials (1979);

(3) Principles of Medical Ethics Relevant to the Role of Health Personnel, particularly Physicians, in the Protection of Prisoners and Detainees against Torture and Other Cruel, Inhuman or Degrading Treatment or Punishment (1982);

(4) Convention against Torture and Other Cruel, Inhuman or Degrading Treatment or Punishment (1984); and

(5) Body of Principles for the Protection of All Persons Under Any Form of Detention or Imprisonment (1988).

Most of these instruments are the product of consistent and skillful efforts of governmental and non-governmental experts. On the governmental side, the contributions of countries like the Netherlands and Sweden were very substantial. On the non-governmental side, much credit should go to Amnesty International and the International Commission of Jurists for their political lobbying and their skillful drafting work, with the constant aim to enhance the level of protection. It would go beyond the scope of this article to review in detail all of the non-governmental input into these instruments, which sometimes consists of proposals for entire documents,

20. See Rodley, supra note 19 , at 26 . 
and in other instances consists of presentation of draft articles or amendments. The 1982 Principles of Medical Ethics were almost entirely the product of non-governmental efforts. They received formal endorsement by the UN General Assembly. These principles were prepared by the Council for International Organizations of Medical Sciences (CIOMS), a non-governmental organization established with the joint sponsorship of the World Health Organization (WHO) and the United Nations Educational, Scientific and Cultural Organization (UNESCO) and submitted to the UN through WHO at the invitation of the General Assembly. ${ }^{21}$ The lengthy drafting process of a convention on the Rights of the Child $^{22}$ mobilized numerous NGOs. Over the years the drafting process took its course in a special working group of the Commission on Human Rights. Some thirty-five organizations established an informal NGO Ad Hoc Group in Geneva in order to consult each other and to arrive at common approaches and common strategies. A leadership role was played by Defence for Children International (DCI). There were, however, some NGOs which preferred to act separately. Many articles of the draft convention, which was finally adopted by UN General Assembly on November 20, 1989, were proposed or influenced by NGOs. The NGO Ad Hoc Group recently noted that the NGO impact became greater after the establishment of the NGO Ad Hoc Group. ${ }^{23}$ The Ad Hoc Group also recognized that on a number of issues, their efforts had remained unsuccessful. Furthermore, the same group noted that it was very much a European/North American body, and it regretted that there had not been more NGO representatives from other parts of the world. ${ }^{24}$ The drafting process of the children's convention created a momentum that rallied interested and dedicated NGOs in many parts of the world. The fact that NGOs largely contributed to the draft convention on the Rights of the Child was officially acknowledged by Mr. Lopatka, the Polish Chairman-Rapporteur of the Working Group on the Question of a Convention on the Rights of the Child, when he presented the draft convention to the Com-

21. Id. at 291-301.

22. The Convention was initiated by Poland when it submitted a draft in 1978 to the Commission on Human Rights based on the 1959 Declaration of the Rights of the Child.

23. Summary of Proceedings of Informal NGO Ad Hoc Group held in Geneva on May $17-19,1989$, at 9.

24. Id. at 13. In this respect it is interesting to note that the present author, when on a mission to Argentina in July 1988 in connection with a UN mandate on disappeared children, was approached by a large coalition of Argentine NGOs in order to discuss the draft convention. 
mission on Human Rights on March 8, 1989. ${ }^{25}$

A third area of human rights standard-setting of special interest to NGOs concerns the rights of indigenous peoples. When the International Bill of Human Rights and subsequent international instruments were drafted, virtually no one involved in the drafting process had in mind the specific rights and interests of indigenous peoples stemming from their collective and distinct characteristics. Their plight became a matter of UN concern only after the comprehensive Study of the Problem of Discrimination against Indigenous Populations has been carried out by Mr. Jose Martinez Cobo, Special Rapporteur of the Sub-Commission on Prevention of Discrimination and Protection of Minorities. ${ }^{26}$ Among its many recommendations the study suggested that the Sub-Commission and its subsidiary organs prepare a declaration of the rights and freedoms of indigenous populations as a possible basis for a convention. The study also recommended that authentic representatives of the world's principal indigenous organizations participate directly in the preparatory work. ${ }^{27}$ And in fact, the evolution of standards of the rights of the indigenous peoples became one of the priority tasks of the Sub-Commission's Working Group on Indigenous Populations, which was created in the early 1980s. The Working Group is presently seized with a revised text of a draft Universal Declaration on the Rights of Indigenous Peoples. ${ }^{28}$ According to the report of the 1989 session of the Working Group, some 135 non-governmental organizations were represented in the Working Group. ${ }^{29}$ They are all entitled to participate and to provide information to the Working Group. In view of the considerable financial burden of travelling to Geneva for indigenous organizations and groups coming from other continents, the United Nations had the care and wisdom to establish a trust fund in order to meet the expenses of a number of indigenous representatives. It should be noted that in UN documents the term "indigenous peoples' organi-

25. U.N. Doc. E./CN.4/1989/SR.54 If 4 \& 9.

26. U.N. Doc. E/CN.4/Sub.2/1986/7 and Addenda, U.N. Sales No. E.86.XIV.3.

27. Id. vol. V, Conclusions, Proposals and Recommendations, If 627-628.

28. See Report of the Working Group on Indigenous Populations on its Seventh Session, U.N. Doc. E/CN.4/Sub.2/1989/36 (in particular Annex II containing the first revised text of the draft Universal Declaration on the Rights of Indigenous Peoples, as presented by the Chairman/Rapporteur, Ms. Erica-Irene Daes).

29. Id at 6-7. (These organizations include approximately 10 indigenous peoples' organizations which have consultative status, 25 other NGOs with consultative status, 70 indigenous peoples' organizations without consultative status but represented with the consent of the Working Group, 30 other organizations and groups without consultative status and also represented with the consent of the Working Group.) 
zations" is now in common use which implies something more and different than the term "non-governmental organizations." 30 This terminological question has some relevance in the discussion of issues of indigenous rights as peoples' rights, and the international personality of indigenous peoples. In addition, the recent revision of the ILO Convention on Indigenous and Tribal Populations (No. 107) of 1957, resulting in the new Indigenous and Tribal Peoples Convention (No. 169) of 1989, drew a great deal of interest on the part of indigenous organizations and groups. It is generally welcomed that the assimilationist thrust of the earlier ILO Convention of 1957 is now replaced by the recognition that indigenous peoples have the right to exist as distinct communities on the foundation of indigenous rights. However, the process leading to the adoption of the new convention, as well as some aspects of that international instrument, gave rise to considerable controversies and misgivings. ${ }^{31}$

\section{Modalities of NGO Cooperation, Contribution and PARTICIPATION}

There are many ways in which NGOs may contribute to the development, adoption and acceptance of international human rights standards. The Campaign for the Abolition of Torture by Amnesty International, together with other factors, prompted governmental and non-governmental actors to embark upon an elaborate program of standard-setting aimed at the abolition and the prevention of torture and related practices. This is a matter of mobilizing public opinion, and exercising public pressure, which sometimes involves parliaments, political parties, churches and other religious bodies, trade unions, professional groups and other organs of national and international society. NGOs also attempt to influence governments and parliaments in order to obtain the acceptance of international human rights treaties through ratification or accession. These activities are important as a counterweight to immobility and lethargy, which are characteristic for quite a few national and international bureaucracies.

Regarding the actual drafting of international standards, NGOs choose to follow different practices and different procedures, de-

30. Barsh, United Nations Seminar on Indigenous Peoples and States, 83 Ам. J. of INT’L L. 599, 602 n.20 (July 1989).

31. Report of the Working Group on Indigenous Populations, supra note 28, at If 29 $31 \& 60$. 
pending on the rules applied by international fora, ${ }^{32}$ the receptivity of these fora to NGO input, and the type of relationships and affinity of NGOs with international secretariats and with governmental delegates. As was previously noted, at the time of the drafting of the International Bill of Human Rights, NGOs were not entitled to make proposals and amendments in their own name. They counted on their good relationships with governmental delegates and cooperated in certain instances closely with them. In more recent practice, although no formal rules of procedure provide for this, NGOs are entitled to put forward drafting proposals in their own name and on the same footing as governmental representatives, at least at the level of working groups. The drafting history in the Commission's Working Groups on the UN Convention against Torture and on the Convention on the Rights of the Child furnished ample evidence of this practice. ${ }^{33}$ At that level of working groups-low in the hierarchy of the UN machinery, but important in terms of legal expertise and technical skills-the NGOs often act as full participants and sometimes as principal actors. The same practice has also developed in working groups and drafting bodies of the UN SubCommission, most recently with respect to draft principles on the rights of the mentally ill and the draft declaration on the protection of all persons from enforced or involuntary disappearances. ${ }^{34} \mathrm{Nev}$ ertheless, the NGO Ad Hoc Group on the Rights of the Child observed at a recent evaluation meeting that "NGOs increasingly realized the relative effectiveness of working with and through a wide range of government delegates instead of trying to push their proposals directly from the floor." 35

There are also quite a few instances of NGOs drawing up complete texts of international instruments on issues which are of special interest to them. One example is the Principles of Medical Ethics, initially drawn up by the Council for International Organizations of Medical Sciences (CIOMS) and finally approved by the UN General Assembly. In early 1978, the International As-

32. For example, working groups, the Sub-Commission and the Commission on Human Rights in the UN.

33. See also Burgers, An Arduous Delivery: The United Nations Convention Against Torture (1984); in Effective Negotiations, Case Studies in Conference Diplomacy 45, 46 (J. Kaufmann ed. 1989).

34. See the 1988 and 1989 Reports of the Working Group on Detention of the SubCommission on Prevention of Discrimination and Protection of Minorities, U.N. Doc. E/ CN.4/Sub.2/1988/28 and E/CN.4/Sub.2/1989/29.

35. Summary of Proceedings of Informal NGO Ad Hoc Working Group, supra note 23 , at 14 . 
sociation of Penal Law (IAPL) proposed a draft convention for the Prevention and Suppression of Torture to the Commission on Human Rights. Nevertheless, the Commission decided to take a Swedish draft as the basis for further work. ${ }^{36}$ Among other drafts elaborated and presented by NGOs to the UN for further action were: (1) a Declaration on the Right to Leave and to Return to one's Country, sponsored by the International Institute of Human Rights and the Jacob Blaustein Institute for the Advancement of Human Rights, ${ }^{37}$ and (2) the draft for a Declaration on the Protection of All Persons from Enforced or Involuntary Disappearances, prepared by the International Commission of Jurists on the basis of informal consultations carried out by ICJ with governmental and non-governmental organizations in Latin America, and also with the Inter-American Commission on Human Rights and the UN Working Group on Enforced or Involuntary Disappearances. ${ }^{38}$ Other NGOs have also elaborated complete texts for normative documents in the field of human rights. These documents have had no immediate effect on UN standard-setting, but were drawn up in the hope that they may have international impact. In this category falls the Algiers Declaration of the Rights of Peoples, elaborated in 1976 under the sponsorship of the International Foundation for the Rights and Liberation of Peoples. ${ }^{38}$ Also, the International Law Association (ILA) has produced normative documents which deserve attention, such as the Paris Minimum Standards of Human Rights Norms in a State of Emergency (1984) ${ }^{40}$ and the Declaration of Principles of International Law on Mass Expulsion (Seoul, 1986). ${ }^{41}$

In the foregoing, the role of NGOs was discussed in relation to preparing the ground and creating the climate for international standard-setting, with regard to their involvement in the actual drafting of international instruments and their role in promoting the wider acceptance of human rights standards. Another role NGOs have assumed is that of elaborating further interpretative rules in connection with already existing international instruments.

36. J. Burgers \& H. Danelius, supra note 19 , at $26 \& 38$.

37. H. Hannum, The Right to Leave and Return in International Law and Practice 154-58, app. F (1987).

38. 1989 Report of the Working Group on Detention, supra note 34, at 12.

39. Rigaux, The Algiers Declaration on the Rights of Peoples, in U.N. LAW/FundAmental Rights, Two Topics in International Law 211-23 (A. Cassese ed., 1979). (1984).

40. International Law Association, Report of the Sixty-First Conference 1, 56ff (1986). 
In 1984, the International Commission of Jurists, together with the International Association of Penal Law and the Urban Morgan Institute of Human Rights, met in Siracusa, Sicily, and drew up definitions and commentaries on the meaning and scope of the derogation and limitation provisions in the International Covenant on Civil and Political Rights. The document that emerged carries the name of "Siracusa Principles." ${ }^{2}$ Two years later, in 1986, the International Commission of Jurists together with the University of Limburg and the Urban Morgan Institute met in Maastricht, Netherlands, and elaborated a set of principles on the nature and scope, of the obligations of the International Covenant on Economic, Social and Cultural Rights, and on the implementation of the Covenant. The result of these efforts is called the "Limburg Principles." ${ }^{43}$ Both the Siracusa Principles and the Limburg Principles were the product of in-depth research and studies by scholars and intense deliberations by human rights experts and practitioners. The Siracusa and the Limburg Principles were not only circulated in UN documents and cited in UN and other studies, they are also occasionally referred to as an authoritative source in the committees that carry out supervisory tasks with respect to the implementation of the two international covenants.

\section{EFFeCtiveness of NGO ACtivities}

NGOs have become increasingly active and effective in their standard-setting work. In the context of the UN and other international organizations, certain skills and qualities are highly important, if not indispensable, for making an impact. Expertise is a key quality, but also important are diplomatic skills, good relationships and contacts, and a clear vision about objectives. Without implying that the NGO Ad Hoc Group on the Rights of the Child was necessarily the most effective model of NGO cooperation and input, it is certainly instructive to read the factors which the Group identified in its evaluation report as contributing to what is considered the success of the Group. Among these factors are: (1) motivation of its membership, (2) tenacity with which it advocated, (3) wide

42. The Siracusa Principles are reproduced in 36 Review of The INT'L Commission of JURISTs, 47-56 (June 1986), and circulated in U.N. Doc. E/CN.4/1985/4 at the request of the Netherlands.

43. The Limburg Principles are reproduced in 37 Review of THE INT'L Commission OF JURISTs 43-55 (Dec. 1986). They were also circulated as a UN document by the Netherlands government; see U.N. Doc. E/CN.4/1987/17. 
range of professional experience it embodied, (4) the professionalism it displayed, (5) the Group's secretariat as a focal point of information and coordination, (6) the presence of UNICEF as a partner, (7) informal social contacts with government delegates, (8) the credibility obtained with the UN Working Group, (9) the constant consultation among NGOs, and (10) the appointment of one NGO spokesperson on specific issues. The NGO Ad Hoc Group also observed that as a group the NGOs had considerable specific expertise to offer which was lacking within the UN. ${ }^{44}$ As noted earlier, the contributions of NGOs rest on two premises according to the rules and regulations for consultative status: the expertise of NGOs and the representative character of NGOs. In the foregoing, the element of expertise was highlighted. The question of representative character also deserves some further attention.

\section{Representative Character of NGOs}

The United Nations Charter was proclaimed in the name of "We the Peoples." The principle decision-makers in the organization are governments of Member States. However, in many instances governments cannot be considered as the genuine representatives of the people over whom they exercise authority. The notion of "We the Peoples" often appears more fiction than fact. In a sympathetic, but not very realistic, effort to correct this state of affairs and to make the United Nations a more truly representative organization, the idea was put forward to create a three-chamber UN General Assembly: a Prince chamber representing the governments, a Merchant Chamber representing the economic powers, and a Citizen Chamber speaking for the people and their associations. ${ }^{45}$ For the time being this interesting utopian idea may be commended to those who work for world federalism. However, when the UN made arrangements for consultation with NGOs it was at least assumed that these NGOs would be of "representative character and of recognized international standing, representing a substantial proportion and expressing the views of major sections of the population or of organized persons within the particular field of its competence, covering, where possible, a substantial number of countries in different regions of the world."46 The United Nations and other inter-

44. Summary of Proceedings of Informal NGO Ad Hoc Working Group, supra note 23 , at $12-14$.

45. Nerfin, supra note 1 , at 24.

46. ECOSOC resolution 1296 (XLIV) I 4. 
governmental organizations based themselves on a neat and balanced division of work between governments on the one hand, and NGOs on the other, each having their own representative and distinct roles.

With the appearance of indigenous peoples' organizations on the international scene, it became clear that existing international structures and arrangements do not fit the perceptions and aspirations of these indigenous organizations. These organizations openly challenge the representative character of governments, and they claim to be the genuine representatives of indigenous communities. At the level of the Sub-Commission's Working Group on Indigenous Populations, a practical solution has been found. In the Working Group, also indigenous organizations that function at the community or national level and are most directly representative of and knowledgeable about conditions and aspirations of their peoples are allowed to participate in the work. This facility is granted in spite of the fact that these organizations do not qualify. for consultative status according to present rules and regulations. It remains to be seen whether this practical solution will also be followed when the draft universal declaration on the rights of indigenous peoples will be discussed at higher levels of the UN hierarchy.

The problems relating to indigenous participation in the revision of the ILO Convention on Indigenous and Tribal Populations (No. 107) of 1957 were already the subject of intense discussion in two recent issues of "The Review of the International Commission of Jurists." ${ }^{47}$ Under ILO rules only international NGOs are allowed to speak in formal sessions, but not organizations which represent indigenous peoples at the community or national levels. The Director of the International Work Group on Indigenous Affairs expressed the misgivings of some indigenous organizations in the following terms: "they were relegated to the rim of the conference hall, looking on aghast as their fundamental rights were discussed, debated, horse-traded and, more often than not, thrown out." ${ }^{.48} \mathrm{~A}$ senior official of the ILO commented that the participation by NGOs in the revision process was greater than at any time in the history of the United Nations system for the adoption of any

47. Berman, The ILO and Indigenous Peoples: Revision of ILO Convention No. 107 at the 75th Session of the International Labour Conference, 1988, in 41 REVIEW OF THE INT'L Commission of Jurists 48-57 (Dec. 1988); Samson \& Swepston, Response to Review 41 Article on ILO Convention, in 42 Review of the INT'L Commission of JURISTS, 43-46 (June 1989).

48. Quoted by Berman, supra note 47 , at 52 . 
human rights instrument. He saw the issue in the light of "a certain amount of conflict among different NGOs over who is truly representative." ${ }^{4 \theta}$ It seems that there is a deeper conflict than suggested by the ILO official. It is a conflict between the presumed representative character of the existing governmental structures and international organizations and institutions on the one hand, and legitimate aspirations of the indigenous peoples on the other hand, inasmuch as the latter wish to exercise the right to self-determination and acquire national and international recognition.

\section{InTERnational Standard-Setting and Democracy}

In modern times international legislation has an increasing impact on domestic legal orders. With the development of the concept and structures of international cooperation, the volume of international legislation is rapidly increasing. Also supra-national structures, such as the European Communities, have extensive law making powers. They issue regulations and directives which are directly applicable within national legal orders and take precedence over national law. With the internationalization of human rights since World War II, the standard-setting activities in that area have been a continuing exercise, and numerous conventions, declarations, codes and sets of principles concerning human rights or human rights-related matters are on the books or are in the process of elaboration.

It is a matter of concern that a great deal of international legislation, which directly or indirectly affects the rights and well being of individuals, groups and entire populations, is the product of national or international bureaucracies without proper democratic control or input. Parliamentary involvement is limited or totally excluded. Parliaments are often faced with texts already completed and adopted. In other words, what is submitted to them are "faits accomplis." A striking example of this kind of phenomenon was the subject of a lively political and legal debate in Western Europe in the fall of $1989 .{ }^{\circ 0}$ In 1985, France, the Federal Republic of Germany, the Netherlands, Belgium and Luxembourg met at Schengen, Luxembourg, and concluded an agreement on the gradual abolition of control on their common borders. In this Schengen

49. Samson \& Swepston, supra note 47 , at 46.

50. Meyers, Refugees in Western Europe; "Schengen" Affects the Entire Refugee Law, Neth. L.J. 1297-1302 (Oct. 21, 1989). 
agreement, the five countries undertook to prepare the harmonization of certain aspects of the law pertaining to aliens. As a followup, officials of the five countries were preparing a supplementary agreement in a climate of secrecy, which inter alia risked to jeopardize some fundamental principles of refugee law as laid down in the UN Convention on the Status of Refugees of 1951. No involvement on the part of parliaments, public opinion or the UN High Commissioner for Refugees was allowed in this legislative process. It was feared that what finally would emerge would be a "fait accompli" by bureaucrats who tend to have the "raison d'état" in their minds. Thanks to the vigilance and protests on the part of the non-governmental sector, and as a result of recent developments in the relations between the Federal Republic of Germany and the German Democratic Republic, the five Schengen countries decided in December 1989 to postpone the conclusion of the supplementary agreement and to review their positions.

The so-called "Schengen" exercise was only an illustration of the old style treaty-making process which predominantly serves state and inter-state interests. We have now, however, entered a new phase in international relations-at least in theory-a phase of international cooperation which is supposed to serve common goals and common interests that are vital for the survival of humankind. After two destructive world wars, the UN Charter introduced the idea of the internationalization of human rights, and the concept of universality of human rights was enshrined in the International Bill of Human Rights. The international law of human rights is a people-oriented law, and it is only natural that the shaping of this law should be a process in which representative sectors of society participate. This is a logical requirement of democracy. While the orientation of contemporary international law and a fortiori of international human rights law is supposed to bend towards serving human and welfare interests, the international law-making process generally follows traditional patterns with a predominant role for states. This is an anomaly and reveals a lack of democratic quality.

It is to the credit of UN working groups involved in human rights standard-setting that they provide ample room to NGO representatives to participate in the proceedings. In fact, NGOs themselves have progressively conquered this space. In a modest way this practice fills a democratic gap. It is sometimes suggested that the present practice should be formalized by devising new rules concerning the NGO role in international standard setting. This 
matter should be approached with some degree of caution, because the end result of such formalization may well have a restrictive effect on present practice. On another occasion the author pleaded for a more coherent standard-setting agenda and for more consistent procedures with respect to the preparation of international instruments in the field of human rights. ${ }^{\mathbf{S 1}}$ Part and parcel of a more coherent, consistent and consolidated practice of international human rights standard setting should be the securing of facilities for non-governmental participation and input. Transparency and public discussion are essential elements of democratic processes. These elements are also needed in international legislation, and NGOs can play an instrumental role in this regard.

51. van Boven, The Future Codification of Human Rights; Status of Deliberation-A Critical Analysis, 10 Hum. RTs. L.J. 1, 11 (1989). 
California Western International Law Journal, Vol. 20, No. 2 [2015], Art. 5 